\title{
Fluorescence and phosphorescence of a series of silicon-containing six-membered-ring molecules
}

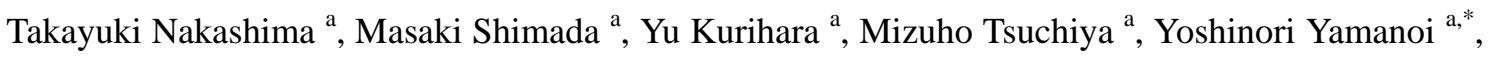
Eiji Nishibori ${ }^{\mathrm{b}}$, Kunihisa Sugimoto ${ }^{\mathrm{c}}$, and Hiroshi Nishihara ${ }^{\mathrm{a},{ }^{*}}$

${ }^{a}$ Department of Chemistry, School of Science, The University of Tokyo, 7-3-1 Hongo, Bunkyo-ku, Tokyo 113-0033, Japan

b Division of Physics, Faculty of Pure and Applied Sciences, Tsukuba Research Center for Interdisciplinary Materials Science (TIMS) \& Center for Integrated Research in Fundamental Science and Engineering (CiRfSE), University of Tsukuba, 1-1-1 Tennodai, Tsukuba, Ibaraki, 305-8571, Japan

${ }^{\mathrm{c}}$ Japan Synchrotron Radiation Research Institute (JASRI), 1-1-1 Koto, Sayo-cho, Sayo-gun, Hyogo, 679-5198, Japan

* Corresponding Authors

TEL: +81-3-5841-4346; FAX: +81-3-5841-8063.

E-mail addresses: yamanoi@chem.s.u-tokyo.ac.jp, nisihara@chem.s.u-tokyo.ac.jp

\begin{abstract}
:
Various silicon-containing six-membered-ring molecules were synthesized by Pd-catalyzed coupling reaction of 1,2-bis(dimethylsilyl)arenes with 1,2-diiodoarenes in moderate yields. Their optical properties were investigated via UV-vis absorption, fluorescence and phosphorescence spectroscopies, which indicated that the $\sigma^{*}-\pi^{*}$ conjugated system expanded owing to the silicon
\end{abstract}


atoms. Some of the compounds exhibited enhanced luminescence, larger Stokes shift, and phosphorescence in comparison with 9,9,10,10-tetramethyl-9,10-dihydroanthracene. Density functional theory (DFT) studies were also performed to investigate the photophysical properties of the compounds.

Key words: Silicon, fluorescence, phosphorescence, DFT

\section{Introduction}

Much recent attention has focused on the unique properties of certain aromatic compounds bridged with hetero-atoms.[1] Red- or blue-shifts emerge in materials with $\sigma-\pi$ conjugation, such as organosilicon compounds, as the energy gap between the HOMO and LUMO is tuned. Silicon-containing $\sigma-\pi$ conjugated molecules are expected to be used in several kinds of materials such as fluorescent-emitting or electron-transporting devices.[2] Adding silicon directly to aromatic molecules induces hyperconjugation between the $\sigma$ orbital of the silicon and the aromatic $\pi$ orbital. UV-vis absorption and fluorescence spectra are red-shifted and the molecule's absorption coefficient and fluorescence intensity increase owing to the $\sigma-\pi$ conjugation. These effects are evident in dibenzosilole, a five-membered ring molecule that contains silicon.[3] However, structurally similar silicon-containing molecules with six-membered-rings have been less well investigated due to limitations of their synthetic methodology.[4] During studies of the reaction between hydrosilanes with aryl iodides, we have shown that this reaction provides a convenient route to various dibenzosiloles and dibenzogermoles.[5] In this work, we synthesized a series of 9,9,10,10-tetramethyl-9,10-dihydro-9,10-disilaanthracene, which are silicon-containing six-membered-ring compounds from their corresponding 1,2-bis(dimethylsilyl)arenes and 1,2-diiodoarenes, and investigated the fluorescence of the compounds at room temperature and their 
phosphorescence at $77 \mathrm{~K}$.

\section{Result and discussion}

Initially, we screened the optimal conditions of coupling reaction between 1,2-bis(dimethylsilyl)benzene and 1,2-diiodobenzene as the model reaction, included the modification of solvents, bases, Pd catalysts, and temperature.[6-8] The reaction was monitored by $\mathrm{GC}$, and the results were summarized in Table 1 . We found that 1,2-diiodobenzene was completely converted at the end of the reaction and that $\mathrm{Pd}\left(\mathrm{P}(t-\mathrm{Bu})_{2}\left(4-\mathrm{Me}_{2} \mathrm{NC}_{6} \mathrm{H}_{4}\right)\right)_{2}$ (catalyst) and $\mathrm{N}, \mathrm{N}$-diisopropylethylamine (base) in 1,2-dichloroethane or propionitrile (solvent) at $\mathrm{rt}$ (temperature) for $1 \mathrm{~d}$ were the best conditions after the careful optimization. Finally, the ratio of 1,2-bis(dimethylsilyl)benzene and 1,2-diiodobenzene was tested, and larger amount of 1,2-bis(dimethylsilyl)benzene could improve the yield of the product (1) in up to $43 \%$. In the improved synthetic protocol, silicon-containing six-membered-ring molecules 1-8 shown in Table 2 were synthesized by coupling 1,2-bis(dimethylsilyl)arenes and 1,2-diiodoarenes under the optimized conditions. Compound 9, the carbon analog of $\mathbf{1}$, was commercially available and used for comparison. Although all the compounds were obtained here in moderate yields in one-step reaction, it was difficult to prepare unsymmetrical 9,10-dihydro-9,10-disilaanthracenes 2-7, including double cyclized product $\mathbf{8}$, using previous methods. Importantly, delicate functional groups toward organometallic reagents such as the ester substituent of $\mathbf{6}$ were compatible with the reaction. The main byproducts were reduced arene compounds and non-cyclized products. Analytically pure compounds 1-8 were isolated by purification with a GPC column (eluent: $\mathrm{CHCl}_{3}$ ) or by recrystallization of the crude product because the separation of cyclized and non-cyclized products was difficult with $\mathrm{SiO}_{2}$ or $\mathrm{Al}_{2} \mathrm{O}_{3}$ column. These pure compounds were stable under air in the solid state and could be stored without special precautions. 
((Insert Table 1))

((Insert Table 2))

The optical properties of compounds 1-9 were investigated by UV-vis absorption, fluorescence, and phosphorescence spectroscopies. The UV-vis and fluorescence spectral data are listed in $\quad$ Table Compound 1, the simplest 9,9,10,10-tetramethyl-9,10-dihydro-9,10-disilaanthracene congener, exhibited UV absorption at 266 nm, $271 \mathrm{~nm}$, and $277 \mathrm{~nm}$ (shoulder peak). The carbon analog, 9,9,10,10-tetramethyl-9,10-dihydroanthracene (9), exhibited absorption at similar wavelengths (256 $\mathrm{nm}, 263 \mathrm{~nm}$, and $271 \mathrm{~nm}$ ). The absorption maxima of $\mathbf{2}$ and $\mathbf{3}$, which contained methyl groups on the aromatic ring, were slightly different from that of $\mathbf{1}$. However, the extended $\pi$-conjugation of 4 caused its absorption maximum to shift to a longer wavelength $(286 \mathrm{~nm})$ with stronger molecular absorption coefficient relative to that of $\mathbf{1}$. Similar to $\mathbf{4}$, the absorption maxima of $\mathbf{5}, \mathbf{6 , 7}$, and $\mathbf{8}$ were also shifted to longer wavelengths, $277 \mathrm{~nm}, 292 \mathrm{~nm}, 297 \mathrm{~nm}$, and $289 \mathrm{~nm}$, respectively. This indicates that conjugated systems were expanded by the introduction of functional group through 1,2-bis(dimethylsilyl)benzene moiety.

((Insert Table 3))

Next, the luminescence of these compounds in hexane solution has been investigated. Compound 1 exhibited very weak fluorescence when excited at $266 \mathrm{~nm}\left(\Phi_{\mathrm{F}}:<0.01\right)$, while 9 (its carbon analog) exhibited fluorescence at $286 \mathrm{~nm}\left(\Phi_{\mathrm{F}}: 0.08\right)$. Compound 1 in hexane showed a lower 
fluorescence quantum yield than did its carbon analog. Similar to the UV absorption behavior, the fluorescence wavelength of $\mathbf{2}$ was close to that of $\mathbf{3}$, whereas the fluorescence maximum of $\mathbf{4}$ was shifted to a longer wave-length and higher quantum yield ( $\left.\Phi_{\mathrm{F}}: 0.13\right)$. Electron-withdrawing groups on the aromatic ring dramatically reduced the fluorescence quantum yield (5 and $\left.\mathbf{6}, \Phi_{\mathrm{F}}: \leq 0.01\right)$. Compound 7 showed red-shifted fluorescence in high quantum yield due to its expanded $\begin{array}{lllllll}\pi \text {-conjugation } & \left(\lambda_{\mathrm{em}}:\right. & 344 & \mathrm{~nm}, & \Phi_{\mathrm{F}}: & 0.09) . & \text { The }\end{array}$ 9,9,10,10-tetramethyl-9,10-dihydro-9,10-disilaanthracenes showed larger Stokes shifts than did 9,9,10,10-tetramethyl-9,10-dihydroanthracene (9), indicating that their conformational changes from the ground state to the fluorescing state are larger than that of the carbon analog. Compound $\mathbf{8}$ showed a fluorescence maximum red-shifted to $354 \mathrm{~nm}$ compared with $\mathbf{1}$ under excitation at $289 \mathrm{~nm}$.

Solid-state optical properties were also investigated (Table 4). Fluorescence in the solid state was different from that in solution; for example, the emission spectra were broadened. All compounds showed small changes in the peak top of fluorescence wavelength. Especially, quantum yield of $\mathbf{7}$ in the solid state were higher than those in solution. The enhanced quantum yield may have been due to the suppression of non-radiative relaxation channels by the rigid structure in the solid state.

((Insert Table 4))

We also investigated the effects of structure on the phosphorescence of the 9,10-dihydro-9,10-disilaanthracenes. Introducing heavier group-14 atoms is expected to increase the phosphorescence of the chromophore compared with the carbon chromophore.[9] The phosphorescence spectra and photophysical data are shown in the supplementary data and in Table 5, respectively. These compounds, with the exception of $\mathbf{7}$, showed long-lived phosphorescence with 
emission bands in the region of 400-460 $\mathrm{nm}$ in frozen 2-methyltetrahydrofuran at $77 \mathrm{~K}$ with quantum efficiencies of 0.01-0.06. For comparison, compound 9, which contained no atoms heavier than carbon, showed very weak phosphorescence. The presence of electron deficient groups caused a significant bathochromic shift (ca. $50 \mathrm{~nm}$ ) of the emission maximum. The decay lifetimes of these phosphorescence ranged from 50 to $100 \mathrm{~ms}$, close to previously reported triplet lifetimes of organosilicon compounds.[10]

((Insert Table 5))

The crystal structure of $\mathbf{6}$ and $\mathbf{8}$ were determined by X-ray diffraction studies. Cell dimensions, data collection and refinement parameters, and selected bond lengths and angles for $6 \mathbf{A}$ and $6 \mathbf{B}$ are listed in Tables S1-S2, and those for $\mathbf{8}$ are in Tables S3-S4. As described in Fig. 1, the structure shows six-membered ring with a boat conformation and the unit cell of $\mathbf{6}$ contains two independent molecules 6A and $6 \mathrm{~B}$ in the crystal. The Si-C distances in this molecule (1.859-1.886 $\AA$ A) were in reasonable agreement with published X-ray value for Si-C distance $(1.88 \AA$ A $)[12]$. Although the crystal structure of $\mathbf{1}$ was reported as single form in crystal with $155^{\circ}$ of the dihedral angle between the benzene ring planes, the crystal structure of $\mathbf{6 A}$ has increased the dihedral angle $\left(164.1^{\circ}\right)$ while that of $\mathbf{6 B}$ has decreased made by the outer benzene rings $\left(143.2^{\circ}\right)$.[13] The ladder compound 8 also yielded crystals suitable for X-ray analysis (Fig. 2). X-ray analysis revealed that this compound crystallized in syn connectivity with four molecules in the unit cell. Conspicuously, one 9,10-dihydro-9,10-disilaanthracence group are less twisted from planarity (dihedral angle: $173.2^{\circ}$ ) compared to those on the opposite side (dihedral angle: $157.7^{\circ}$ ). In both cases, there was no $\pi-\pi$ stacking in crystal structure to suppress the intermolecular interaction. The variations in dihedral angle may result from a balance between pseudoaxial and pseudoequatorial methyl substituents in 
crystal packing.

((Insert Fig. 1))

((Insert Fig. 2))

Density functional theory (DFT) calculations were performed to explore the effect of silicon atom binding. Molecular orbitals and their energy levels calculated by DFT are summarized in Fig. S40. We initially compared the result of compounds $\mathbf{1}$ and $\mathbf{9}$, whose calculated structures of the bent and planar frameworks were in good agreement with the X-ray analysis.[14,15] The calculations indicated that the introduction of silicon atoms had little effect on the HOMO, but lowered the LUMO energy level owing to the $\sigma^{*}-\pi^{*}$ interaction between the silyl group and the $\pi$-electron system. This explains the HOMO-LUMO gap of the structurally modified 9,9,10,10-tetramethyl-9,10-dihydroanthracene well, because an extended $\pi$-electron system usually has a lower HOMO-LUMO gap.

The HOMO orbital of each compound is mainly concentrated on the electron-rich aromatic ring, whereas the LUMO orbital is located over the whole molecule through the silicon atom with the exception of $\mathbf{6}$. The orbital energies of both HOMO and LUMO increase relative to those of $\mathbf{1}$ upon the introduction of an electron-rich functional group. The HOMO-LUMO gap of $\mathbf{4}$ is slightly lower than that of $\mathbf{2}$ and $\mathbf{3}$, which is attributed to the red-shift of $\mathbf{4}$. The introduction of a fluorine atom (5) and ester groups (6) on the benzene ring lowered the LUMO energy level. The 5,12-dihydro-5,12-disilanaphthacene and 5,7,12,14-tetrahydro-5,7,12,14-tetrasilapentacene linkages (7 and 8) were responsible for smaller HOMO-LUMO gaps than those in compounds with 9,10-dihydro-9,10-disilaanthracene linkages (1-6) due to the expanded $\pi$-conjugation. Orbitals of 6 reveal that the electron density is distributed over the ester moiety with little hyperconjugation. The 
introduction of the ester groups significantly decreases the energy level of the $\pi^{*}$ orbital of the aromatic ring. The inability of this orbital to interact with the $\sigma^{*}$ orbitals of the Si-C bonds leads to electrons to be localized on the electron-withdrawing aromatic group.

\section{Conclusion}

We investigated the synthesis and optical properties of a series of 9,9,10,10-tetramethyl-9,10-dihydro-9,10-disilaanthracene. Hyperconjugation led to the expansion of the $\sigma^{*}-\pi^{*}$ conjugated system especially in the excited state, causing these compounds to display both fluorescent and phosphorescent emissions in the violet to blue region. The proposed method of forming molecules with six-membered-rings containing silicon might be applicable to the synthesis of other kinds of silicon-containing-ring molecules. Moreover, this research can contribute to the development of blue light-emitting devices using their phosphorescent properties.

\section{Experimental section}

General considerations

All melting points were measured with a Yanaco Micro Melting Point apparatus and uncorrected. NMR spectra were measured with a JEOL AL-400 spectrometer or a Bruker DRX-500 spectrometer and referenced to an internal standard of tetramethylsilane $(0.00 \mathrm{ppm})$ for ${ }^{1} \mathrm{H}$ NMR and $\mathrm{CDCl}_{3}(77.0 \mathrm{ppm})$ for ${ }^{13} \mathrm{C}$ NMR. GC-MS spectra were recorded with a Shimadzu GC-MS-QP2010 spectrometer. Purification by preparative HPLC was carried out by using Japan Analytical Industry LC-908 apparatus with GPC or ODS columns. HRMS was performed on a double-focusing sector mass spectrometer in FAB mode with a JEOL JMS 700P FAB MS. UV-vis absorption spectra were 
measured with a UV JASCO V-570 spectrometer. Fluorescence spectra were measured with a Hitachi F-4500 spectrometer. Fluorescent quantum yields were recorded with a Hamamatsu C9920-01 with an integrating sphere. Low-temperature phosphorescence measurements were performed by cooling a solution of the materials in 2-methyltetrahydrofuran to $77 \mathrm{~K}$. Phosphorescent quantum yields were determined by optically dilute measurements with benzophenone in EtOH (quantum yield of $\Phi_{\mathrm{p}}=0.88$ at $77 \mathrm{~K}$ ) as the reference:

$$
\Phi_{\mathrm{s}}=\Phi_{\mathrm{r}} \times\left(I_{\mathrm{s}} / I_{\mathrm{r}}\right) \times\left(A_{\mathrm{r}} / A_{\mathrm{s}}\right) \times\left(n_{\mathrm{s}}{ }^{2} / n_{\mathrm{r}}{ }^{2}\right)
$$

where $I$ is the integrated area of the phosphorescence spectrum, $A$ is the absorbance at the same excitation wavelength, and $n$ is the refractive index of the solvent used. Subscripts $\mathrm{s}$ and $\mathrm{r}$ donate the sample and reference, respectively.[14,15] Fluorescence and phosphorescence lifetimes were measured by Hamamatsu C11367 apparatus.

\section{Materials}

All reagents were commercially available and used without any purification. Solvents were distilled and dried by standard methods for the synthesis. Dimethyl 4,5-diiodo-1,2-benzenedicarboxylate,[16] 1,2,4,5-tetrakis(dimethylsilyl)benzene,[17] 1,2-diiodo-4,5-dimethylbenzene[18] and 1,2-diiodo-4,5-dimethoxybenzene[18] were prepared according to previously described procedures. 1,2-Dimethyl-4,5-bis(dimethylsilyl)benzene and 1,2-dimethoxy-4,5-bis(dimethylsilyl)benzene were synthesized by modified methods based on the literature.[19] 
Synchrotron radiation (SR) X-ray diffraction data of $\mathbf{6}$ were collected at $100 \mathrm{~K}$. The diffractions were recorded on a CCD detector at SPring-8 beam line BL02B1 (Hyogo, Japan). The total number of observed reflections was $66987\left(2 \theta<20.135^{\circ} ; \mathrm{d}>0.60 \AA\right)$. The number of unique reflections was 9368. The structure was solved by direct methods using SIR-2004 and was refined by the full-matrix least-squares techniques against $F^{2}$ implementing SHELXL-2013.

X-ray diffraction data of $\mathbf{8}$ were collected at $113 \mathrm{~K}$ with an AFC10 diffractometer coupled with a Rigaku Saturn CCD system equipped with a rotating-anode X-ray generator producing graphite-monochromated MoKa radiation. Lorentz-polarization and empirical absorption corrections were performed with the program Crystal Clear 1.3.6. The structures were solved by the direct method using SIR-92 program and refined by the full-matrix least-squares techniques against $F^{2}$ implementing SHELXL-97.

CCDC numbers 1411405 and 1444280 contain the supplementary crystallographic data for compound $\mathbf{6}$ and $\mathbf{8}$, respectively. These data can be obtained free of charge from The Cambridge Crystallographic Data Centre via www.ccdc.cam.ac.uk/data_request/cif.

\section{Computational Methods}

All calculations were performed at the B3LYP/6-31G* level to extract theoretical electronic properties and correlated with experimental trends.

Typical experimental procedure for the preparation of 9,9,10,10-tetramethyl-9,10-dihydro-9,10-disilaanthracene by coupling of 1,2-bis(dimethylsilyl)arene and 1,2-diiodoarene 
1,2-Diiodoarene, 1,2-bis(dimethylsilyl)arene (1.5 equiv), and N,N-diisopropylethylamine (6.0 equiv) were added to a solution of $\mathrm{Pd}\left(\mathrm{P}(t-\mathrm{Bu})_{2}\left(4-\mathrm{NMe}_{2} \mathrm{C}_{6} \mathrm{H}_{4}\right)\right)_{2} \quad(0.05$ equiv) in 1,2-dichloroethane $(0.5 \mathrm{M})$. The reaction progress was monitored by GC or TLC. After the atarting material was consumed at room temperature $(1 \mathrm{~d})$, the reaction mixture was quenched with water. The aqueous layer was extracted with dichloromethane three times and dried over sodium sulfate. The combined organic layer was analyzed by GC to estimate the yield of product with dodecane as an internal standard. The solvent was removed under reduced pressure and purified roughly by flash column chromatography over silica gel. In the case of $\mathbf{7}$, the yield was estimated by ${ }^{1} \mathrm{H}$ NMR analysis at this stage. The methyl proton integrals at $\delta 0.56$ vs 0.68 and $0.88 \mathrm{ppm}$ can be measured separately and used to determine the ratio of cyclized and non-cyclized products. Analytical pure products were isolated by the purification of crude products with GPC (eluent: $\mathrm{CHCl}_{3}$ ) and/or recrystallization from methanol.

9,9,10,10-Tetramethyl-9,10-dihydro-9,10-disilaanthracene (1).[4a-c] GC yield: $43 \%$. Isolated yield of analytically pure compound: $29 \%$. Colorless solid. Eluent for TLC: hexane. ${ }^{1} \mathrm{H}$ NMR (500 MHz, $\left.\mathrm{CDCl}_{3}\right) \delta 7.69(\mathrm{dd}, 4 \mathrm{H}, J=3.3,5.5 \mathrm{~Hz}), 7.42(\mathrm{dd}, 4 \mathrm{H}, J=3.3,5.5 \mathrm{~Hz}), 0.48(\mathrm{~s}$, 12H). ${ }^{13} \mathrm{C}$ NMR $\left(125 \mathrm{MHz}, \mathrm{CDCl}_{3}\right) \delta 144.5\left(\mathrm{C}_{\mathrm{q}}\right), 133.4(\mathrm{CH}), 128.3(\mathrm{CH}), 0.0\left(\mathrm{CH}_{3}\right) . \mathrm{EI}-\mathrm{MS} \mathrm{m} / \mathrm{z}$ $268\left(\mathrm{M}^{+}\right)$.

2,9,9,10,10-Pentamethyl-9,10-dihydro-9,10-disilaanthracene (2). GC yield: 27\%. Isolated yield of analytically pure compound: $12 \%$. Colorless solid. Eluent for TLC: hexane. Mp: 69.0-70.0 ${ }^{\circ} \mathrm{C} .{ }^{1} \mathrm{H}$ NMR $\left(500 \mathrm{MHz}, \mathrm{CDCl}_{3}\right) \delta 7.68(\mathrm{dd}, 2 \mathrm{H}, J=3.2,5.4 \mathrm{~Hz}), 7.59(\mathrm{~d}, 1 \mathrm{H}, J=7.4 \mathrm{~Hz})$, $7.50(\mathrm{~s}, 1 \mathrm{H}), 7.41(\mathrm{dd}, 2 \mathrm{H}, J=3.3,5.5 \mathrm{~Hz}), 7.25(\mathrm{~d}, 1 \mathrm{H}, J=7.4 \mathrm{~Hz}), 2.39(\mathrm{~s}, 3 \mathrm{H}), 0.47(\mathrm{~s}, 6 \mathrm{H}), 0.46$ (s, 6H). ${ }^{13} \mathrm{C}$ NMR $\left(125 \mathrm{MHz}, \mathrm{CDCl}_{3}\right) \delta 144.7\left(\mathrm{C}_{\mathrm{q}}\right), 144.6\left(\mathrm{C}_{\mathrm{q}}\right), 144.4\left(\mathrm{C}_{\mathrm{q}}\right), 140.7\left(\mathrm{C}_{\mathrm{q}}\right), 137.9\left(\mathrm{C}_{\mathrm{q}}\right)$, $134.1(\mathrm{CH}), 133.5(\mathrm{CH}), 133.3(\mathrm{CH}), 129.3(\mathrm{CH}), 128.2(\mathrm{CH}), 21.6\left(\mathrm{CH}_{3}\right), 0.13\left(\mathrm{CH}_{3}\right), 0.06\left(\mathrm{CH}_{3}\right)$. EI-MS $m / z 282\left(\mathrm{M}^{+}\right)$. HRMS (FAB) $m / z\left[\mathrm{M}-\mathrm{CH}_{3}\right]^{+}$Calcd for $\mathrm{C}_{16} \mathrm{H}_{19} \mathrm{Si}_{2} 267.1025$; found 267.1020. 
2,3,9,9,10,10-Hexamethyl-9,10-dihydro-9,10-disilaanthracene (3). GC yield: 23\%. Isolated yield of analytically pure compound: $11 \%$. Colorless solid. Eluent for TLC: hexane. Mp: 112.0-113.2 ${ }^{\circ} \mathrm{C} .{ }^{1} \mathrm{H}$ NMR $\left(400 \mathrm{MHz}, \mathrm{CDCl}_{3}\right) \delta 7.67(\mathrm{dd}, 2 \mathrm{H}, J=3.3,5.5 \mathrm{~Hz}), 7.44(\mathrm{~s}, 2 \mathrm{H}), 7.40(\mathrm{dd}$, $2 \mathrm{H}, J=3.2,5.4 \mathrm{~Hz}), 2.31(\mathrm{~s}, 6 \mathrm{H}), 0.45(\mathrm{~s}, 12 \mathrm{H}) .{ }^{13} \mathrm{C} \mathrm{NMR}\left(100 \mathrm{MHz}, \mathrm{CDCl}_{3}\right) \delta 144.8\left(\mathrm{C}_{\mathrm{q}}\right), 141.5$ $\left(\mathrm{C}_{\mathrm{q}}\right), 136.9\left(\mathrm{C}_{\mathrm{q}}\right), 134.9(\mathrm{CH}), 133.3(\mathrm{CH}), 128.2(\mathrm{CH}), 19.8\left(\mathrm{CH}_{3}\right), 0.2\left(\mathrm{CH}_{3}\right)$. FAB-MS m/z 297 $\left([\mathrm{M}+\mathrm{H}]^{+}\right)$. HRMS (FAB) $m / z:[\mathrm{M}+\mathrm{H}]^{+}$Calcd for $\mathrm{C}_{18} \mathrm{H}_{25} \mathrm{Si}_{2}$ 297.1495; found 297.1479.

2,3-Dimethoxy-9,9,10,10-tetramethyl-9,10-dihydro-9,10-disilaanthracene (4). GC yield: $37 \%$. Isolated yield of analytically pure compound: $10 \%$. Colorless solid. Eluent for TLC: hexane / ethyl acetate $=10 / 1 . \mathrm{Mp}: 147.0-148.0{ }^{\circ} \mathrm{C} .{ }^{1} \mathrm{H}$ NMR $\left(400 \mathrm{MHz}, \mathrm{CDCl}_{3}\right) \delta 7.67(\mathrm{dd}, 2 \mathrm{H}, J=3.2,5.4$ $\mathrm{Hz}), 7.41(\mathrm{dd}, 2 \mathrm{H}, J=3.2,5.4 \mathrm{~Hz}), 7.16(\mathrm{~s}, 2 \mathrm{H}), 3.95(\mathrm{~s}, 6 \mathrm{H}), 0.47(\mathrm{~s}, 12 \mathrm{H}) .{ }^{13} \mathrm{C}$ NMR $(125 \mathrm{MHz}$, $\left.\mathrm{CDCl}_{3}\right) \delta 149.4\left(\mathrm{C}_{\mathrm{q}}\right), 144.5\left(\mathrm{C}_{\mathrm{q}}\right), 136.6\left(\mathrm{C}_{\mathrm{q}}\right), 133.3(\mathrm{CH}), 128.2(\mathrm{CH}), 115.9(\mathrm{CH}), 55.7\left(\mathrm{CH}_{3}\right), 0.2$ $\left(\mathrm{CH}_{3}\right)$. EI-MS $\mathrm{m} / \mathrm{z} 328\left(\mathrm{M}^{+}\right)$. HRMS (FAB) $\mathrm{m} / \mathrm{z}:[\mathrm{M}+\mathrm{H}]^{+}$Calcd for $\mathrm{C}_{18} \mathrm{H}_{25} \mathrm{O}_{2} \mathrm{Si}_{2}$ 329.1393; found 329.1402 .

2-Fluoro-9,9,10,10-tetramethyl-9,10-dihydro-9,10-disilaanthracene (5). GC yield: $27 \%$. Isolated yield of analytically pure compound: $11 \%$. Colorless solid. Mp: $68.3-68.7{ }^{\circ} \mathrm{C}$. Eluent for TLC: hexane. ${ }^{1} \mathrm{H}$ NMR $\left(500 \mathrm{~Hz}, \mathrm{CDCl}_{3}\right) \delta 7.69-7.65(\mathrm{~m}, 3 \mathrm{H}), 7.43-7.41(\mathrm{~m}, 2 \mathrm{H}), 7.36(\mathrm{dd}, 1 \mathrm{H}, J=$ 2.7, $9.3 \mathrm{~Hz}), 7.10(\mathrm{ddd}, 2 \mathrm{H}, J=2.5,8.2,9.5 \mathrm{~Hz}), 0.47(\mathrm{~d}, 12 \mathrm{H}, J=5.7 \mathrm{~Hz}) .{ }^{13} \mathrm{C} \mathrm{NMR}(125 \mathrm{MHz}$, $\left.\mathrm{CDCl}_{3}\right) \delta 163.2\left(\mathrm{C}_{\mathrm{q}}, J=251.1 \mathrm{~Hz}\right), 148.0\left(\mathrm{C}_{\mathrm{q}}, J=3.7 \mathrm{~Hz}\right), 144.3\left(\mathrm{C}_{\mathrm{q}}\right), 143.8\left(\mathrm{C}_{\mathrm{q}}\right), 139.8\left(\mathrm{C}_{\mathrm{q}}, J=3.7\right.$ $\mathrm{Hz}), 135.6(\mathrm{CH}, J=6.4 \mathrm{~Hz}), 133.4(\mathrm{CH}, J=2.8 \mathrm{~Hz}), 128.4(\mathrm{CH}, J=10.1 \mathrm{~Hz}), 119.8(\mathrm{CH}, J=17.4$ Hz), $115.6(\mathrm{CH}, J=19.3 \mathrm{~Hz}), 0.13\left(\mathrm{CH}_{3}\right),-0.16\left(\mathrm{CH}_{3}\right)$. EI-MS $\mathrm{m} / z 286\left(\mathrm{M}^{+}\right)$. HRMS (FAB) $\mathrm{m} / z$ : $\left[\mathrm{M}-\mathrm{CH}_{3}\right]^{+}$Calcd for $\mathrm{C}_{15} \mathrm{H}_{16} \mathrm{~F}_{2} \mathrm{Si}_{2}$ 271.0775; found 271.0774.

Dimethyl 9,9,10,10-tetramethyl-9,10-dihydro-9,10-disilanthracene-2,3-dicarboxylate (6). GC yield: $25 \%$. Isolated yield of analytically pure compound: $7 \%$. Colorless solid. Mp: $91.5-92.7{ }^{\circ} \mathrm{C}$. Eluent for TLC: hexane. ${ }^{1} \mathrm{H}$ NMR $\left(500 \mathrm{~Hz}, \mathrm{CDCl}_{3}\right) \delta 7.99(\mathrm{~s}, 2 \mathrm{H}), 7.69(\mathrm{dd}, 2 \mathrm{H}, J=3.3,5.5 \mathrm{~Hz})$, 
$7.44(\mathrm{dd}, 2 \mathrm{H}, J=3.2,5.7 \mathrm{~Hz}), 3.93(\mathrm{~s}, 6 \mathrm{H}), 0.50(\mathrm{~s}, 12 \mathrm{H}) .{ }^{13} \mathrm{C} \mathrm{NMR}\left(125 \mathrm{MHz}, \mathrm{CDCl}_{3}\right) \delta 168.5$ $(\mathrm{C}=\mathrm{O}), 149.2\left(\mathrm{C}_{\mathrm{q}}\right), 143.4\left(\mathrm{C}_{\mathrm{q}}\right), 133.5(\mathrm{CH}), 133.0(\mathrm{CH}), 130.9\left(\mathrm{C}_{\mathrm{q}}\right), 128.7(\mathrm{CH}), 52.7\left(\mathrm{CH}_{3}\right),-0.26$ $\left(\mathrm{CH}_{3}\right)$. EI-MS $m / z 284\left(\mathrm{M}^{+}\right)$. HRMS (FAB) $\mathrm{m} / \mathrm{z}$ : $[\mathrm{M}+\mathrm{H}]^{+}$Calcd for $\mathrm{C}_{20} \mathrm{H}_{25} \mathrm{O}_{4} \mathrm{Si}_{2}$ 385.1293; found 385.1269 .

5,5,12,12-Tetramethyl-5,12-dihydro-5,12-disilanaphthacene (7). NMR yield: 39\%. Isolated yield of analytically pure compound: $12 \%$. Colorless solid. Eluent for TLC: hexane. Mp: 131.5-132.5 ${ }^{\circ} \mathrm{C} .{ }^{1} \mathrm{H}$ NMR $\left(500 \mathrm{MHz}, \mathrm{CDCl}_{3}\right) \delta 8.17(\mathrm{~s}, 2 \mathrm{H}), 7.86(\mathrm{dd}, 2 \mathrm{H}, J=3.2,6.1 \mathrm{~Hz}), 7.73(\mathrm{dd}$, $2 \mathrm{H}, J=3.2,5.4 \mathrm{~Hz}), 7.51(\mathrm{dd}, 2 \mathrm{H}, J=3.3,6.2 \mathrm{~Hz}), 7.44(\mathrm{dd}, 2 \mathrm{H}, J=3.2,5.6 \mathrm{~Hz}), 0.56(\mathrm{~s}, 2 \mathrm{H}) .{ }^{13} \mathrm{C}$ $\operatorname{NMR}\left(125 \mathrm{MHz}, \mathrm{CDCl}_{3}\right) \delta 144.7\left(\mathrm{C}_{\mathrm{q}}\right), 140.5\left(\mathrm{C}_{\mathrm{q}}\right), 133.7(\mathrm{CH}), 133.4(\mathrm{CH}), 132.9\left(\mathrm{C}_{\mathrm{q}}\right), 128.4(\mathrm{CH})$, 127.8 (CH), $126.5(\mathrm{CH}), 0.2\left(\mathrm{CH}_{3}\right)$. EI-MS $m / z 318\left(\mathrm{M}^{+}\right)$. HRMS (FAB) $m / z: \mathrm{M}^{+}$Calcd for $\mathrm{C}_{20} \mathrm{H}_{22} \mathrm{Si}_{2}$ 318.1260; found 318.1239.

5,5,7,7,12,12,14,14-octamethyl-5,7,12,14-tetrahydro-5,7,12,14-tetrasilapentacene (8). GC yield: $15 \%$. Isolated yield of analytically pure compound: 4\%. Colorless solid. Eluent for TLC: hexane. Mp: 202.0-205.0 ${ }^{\circ} \mathrm{C} .{ }^{1} \mathrm{H}$ NMR (500 MHz, $\left.\mathrm{CDCl}_{3}\right) \delta 7.96$ (s, 2H), 7.69 (dd, 4H, $J=3.4,5.4$ $\mathrm{Hz}), 7.42(\mathrm{dd}, 4 \mathrm{H}, J=3.2,5.4 \mathrm{~Hz}), 0.51(\mathrm{~s}, 24 \mathrm{H}) .{ }^{13} \mathrm{C} \mathrm{NMR}\left(125 \mathrm{MHz}, \mathrm{CDCl}_{3}\right) \delta 144.4\left(\mathrm{C}_{\mathrm{q}}\right), 144.0$ $\left(\mathrm{C}_{\mathrm{q}}\right), 137.7(\mathrm{CH}), 133.3(\mathrm{CH}), 128.3(\mathrm{CH}), 0.0\left(\mathrm{CH}_{3}\right)$. EI-MS m/z $458\left(\mathrm{M}^{+}\right)$. HRMS (FAB) $m / z: \mathrm{M}^{+}$ Calcd for $\mathrm{C}_{26} \mathrm{H}_{34} \mathrm{Si}_{4} 458.1738$; found 458.1743 .

\section{Acknowledgments}

The work was financially supported by supported by CREST from JST, Tokyo Kasei Chemical Promotion foundation, and Grant-in-Aids for Scientific Research (C) (No. 15K05604), Scientific Research on Innovative Areas "Molecular Architectonics: Orchestration of Single Molecules for Novel Functions" (area 2509, Nos. 26110505 and 26110506) from the Ministry of Education, Culture, Sports, Science, and Technology, Japan. The synchrotron radiation experiments 
were performed at the SPring-8 with the approval of the Japan Synchrotron Radiation Research Institute (JASRI) (Proposal No. 2015A1367).

\section{Appendix A. Supplementary data}

CCDC 1411405 and 1444280 contain the supplementary crystallographic data for compound $\mathbf{6}$ and 8, respectively. Supplementary data related to this article can be found at http://dx.doi.org/10.1016.

\section{REFERENCES}

[1] (a) F. Jäkle, Chem. Rev. 110 (2010) 3985-4022.

(b) Y. Shirota, H. Kageyama, Chem. Rev. 107 (2007) 953-1010.

(c) T. Baumgartner, R. Réau, Chem. Rev. 106 (2006) 4681-4727.

(d) D. Fichou, Handbook of Oligo- and Polythiophenes; Wiley-VCH: Weinheim, 1999.

[2] (a) H. Sakurai, Pure Appl. Chem. 59 (1987) 1637-1646.

(b) S. Yamaguchi, K. Tamao, J. Chem. Soc. Dalton Trans. (1998) 3693-3702.

(c) S. Yamaguchi, C. Xu, T. Okamoto, Pure Appl. Chem. 78 (2006) 721-730.

(d) J. Y. Corey, Adv. Organomet. Chem. 59 (2011) 1-52.

(e) M. Shimizu, T. Hiyama, Synlett 23 (2012) 973-989.

(f) M. Shimizu, J. Synth. Org. Chem., Jpn. 71 (2013) 307-318.

(g) The Chemistry of Organic Silicon Compounds, Volume 2, Z. Rappoport, Y. Apeloig, Eds.: Wiley: Chichester, 1998.

[3] J. Y. Corey, Adv. Organomet. Chem. 59 (2011) 181-328.

[4] (a) W. Z. McCarthy, J. Y. Corey, E. R. Corey, Organometallics 3 (1984) 255-263.

(b) A. Kawachi, A. Tani, K. Machida, Y. Yamamoto, Organometallics 26 (2007) 4697-4699. 
(c) A. Kawachi, T. Teranishi, T. Deguchi, Y. Yamamoto, Heteroatom Chem. 24 (2013) 53-57.

(d) J. Y. Corey, W. Z. McCarthy, J. Organomet. Chem. 271 (1984) 319-326.

(e) S. Kyushin, T. Shinnai, T. Kubota, H. Matsumoto, Organometallics 16 (1997) 3800-3804.

(f) H. Gilman, E. A. Zuech, J. Am. Chem. Soc. 82 (1960) 3605-3608.

(g) K. Nishiyama, M. Oba, H. Takagi, T. Saito, Y. Imai, I. Motoyama, S. Ikuta, H. Hiratsuka, J. Organomet. Chem. 626 (2001) 32-36.

(h) M. Oba, Y. Kawahara, R. Yamada, H. Mizuta, K. Nishiyama, J. Chem. Soc. Perkin Trans 2 (1996) 1843-1848.

(i) A. Kawachi, T. Teranishi, Y. Yamamoto, Tetrahedron Lett. 50 (2009) 1226-1228.

(j) K. M. Welsh, J. Y. Corey, Organometallics 6 (1987) 1393-1398.

[5] Y. Yabusaki, N. Ohshima, H. Kondo, T. Kusamoto, Y. Yamanoi, H. Nishihara, Chem. Eur. J. 16 (2010) 5581-5585.

[6] M. Murata, K. Suzuki, S. Watanabe, Y. Masuda, J. Org. Chem. 62, (1997) 8569-8571.

[7] (a) Y. Yamanoi, J. Org. Chem. 70 (2005) 9607-9609.

(b) Y. Yamanoi, T. Taira, J.-i. Sato, I. Nakamula, H. Nishihara, Org. Lett. 9 (2007) 4543-4546.

(c) Y. Yamanoi, H. Nishihara, J. Synth. Org. Chem., Jpn. 67 (2009) 778-786.

(d) A. Lesbani, H. Kondo, Y. Yabusaki, M. Nakai, Y. Yamanoi, H. Nishihara, Chem. Eur. J. 16 (2010) $13519-13527$.

(e) A. Lesbani, H. Kondo, J.-i. Sato, Y. Yamanoi, H. Nishihara, Chem. Commun. 46, (2010) 7784-7786.

(f) H. Inubushi, Y. Hattori, Y. Yamanoi, H. Nishihara, J. Org. Chem. 79 (2014) 2974-2979.

(g) M. Shimada, Y. Yamanoi, T. Matsushita, T. Kondo, E. Nishibori, A. Hatakeyama, K. Sugimoto, H. Nishihara, J. Am. Chem. Soc. 137 (2015) 1024-1027.

[8] (a) H. Li, G. A. Grasa, T. J. Colacot, Org. Lett. 12 (2010) 3332-3335. 
(b) X. Pu, H. Li, J. T. Colacot, J. Org. Chem. 78 (2013) 568-581.

(c) H. Li, C. C. C. J. Seechurn, T. J. Colacot, ACS Catal. 2 (2012) 1147-1164.

[9] J. R. Lakowicz, Principles of Fluorescence Spectroscopy 2nd Ed. Kluwer Academic/Plenum Publishers, New York, 1999.

[10] J. H. Kwon, S. T. Lee, S. C. Shim, M. Hoshino, J. Org. Chem. 59 (1994) 1108-1114.

[11] A. Kobayashi, K. Suzuki, T. Yoshihara, S. Tobita, Chem. Lett. 39 (2010) 282-283.

[12] G. Wilkinson, Comprehensive Organometallic Chemistry Vol. 1, Pergamon Press, Elmsford, NY, 1982.

[13] (a) O. A. D'yachenko, L. O. Atovmyan, S. V. Soboleva, T. Y. Markova, N. G. Komalenkova, L. N. Shamshin, E. A. Chernyshev, Zh. Strukt. Khim. 15 (1974) 170-171.

(b) O. A. D'yachenko, L. O. Atovmyan, S. V. Soboleva, T. Y. Markova, N. G. Komalenkova, L. N. Shamshin, E. A. Chernyshev, Zh. Strukt. Khim. 15 (1974) 667-674.

[14] S. G. Makarov, K. N. Maksimova, E. V. Baranov, G. K. Fukin, O. N. Suvorova, D. Wö hrle, G. A. Domrachev, Russ. Chem. Bull. 55 (2006) 1748-1756.

[15] G. A. Crosby, J. N. Demas, J. Phys. Chem. 75 (1971) 991-1024.

[16] M. Dudič, I. Císařová, J. Michl, J. Org. Chem. 77 (2012) 68-74.

[17] Y.-L. Chen, J.-Q. Sun, X. Wei, W.-Y. Wong, A. W. M. Lee, J. Org. Chem. 69 (2004) 7190-7197.

[18] S. V. Kovalenko, S. Peabody, M. Manoharan, R. J. Clark, I. V. Alabugin, Org. Lett. 6 (2004) 2457-2460.

[19] (a) R. P. Bonar-Law, A. P. Davis, B. J. Dorgan, Tetrahedron 49 (1993) 9855-9866.

(b) T. Kitamura, Z. Meng, Y. Fujiwara, Tetrahedron Lett. 41 (2000) 6611-6614. 
Figures

(a)

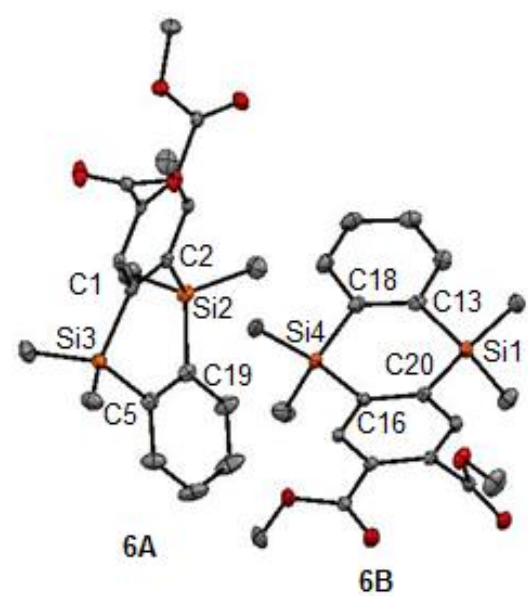

(b)

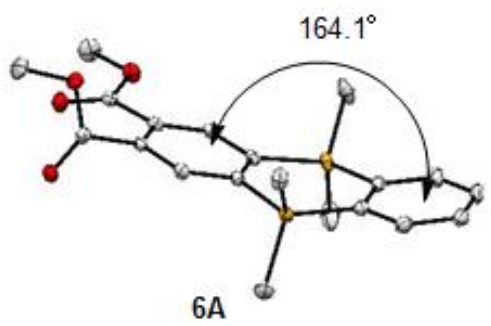

(c)

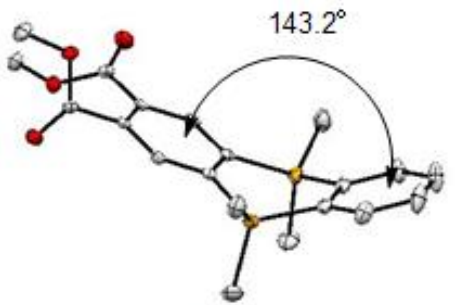

$6 \mathrm{~B}$

Fig. 1

(a) ORTEP drawing of alternating independent $6 \mathbf{A}$ and $6 \mathbf{B}$ units in the crystal structure of $\mathbf{6}$. Thermal ellipsoids are shown at the $50 \%$ probability level. Hydrogen atoms are omitted for clarity. (b) Dihedral angle of 6A. (c) Dihedral angle of $6 \mathbf{B}$. 
(a)

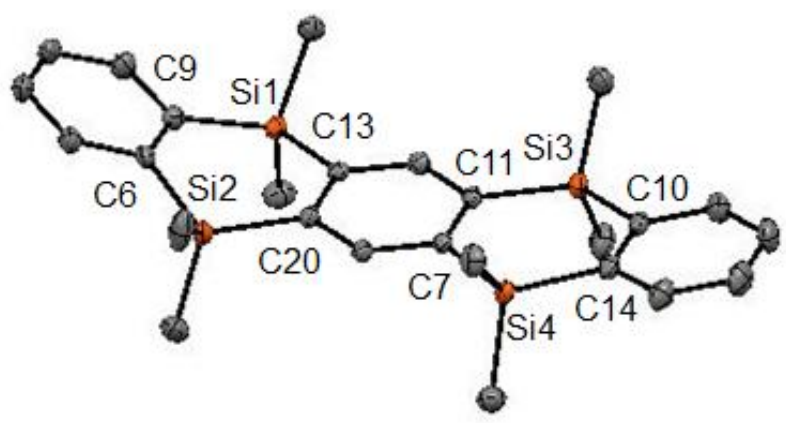

(b)
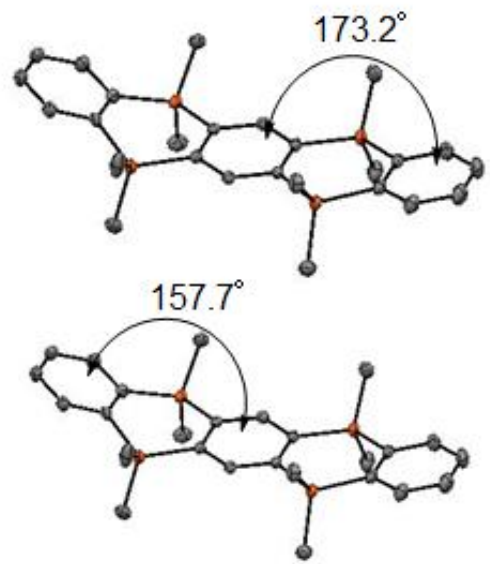

Fig. 2

(a) ORTEP drawing of crystal structure of $\mathbf{8}$. Thermal ellipsoids are shown at the $50 \%$ probability level. Hydrogen atoms are omitted for clarity. (b) Dihedral angle of $\mathbf{8}$. 


\section{Tables}

\section{Table 1}

Screening of optimal reaction conditions for 9,9,10,10-tetramethyl-9,10-dihydro-9,10-disilaanthracene (1).

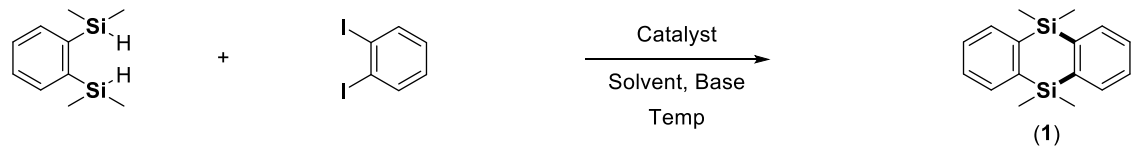

(1)

\begin{tabular}{|c|c|c|c|c|c|c|}
\hline Entry & Catalyst & Temp $\left({ }^{\circ} \mathrm{C}\right)$ & Solvent & Base & $\begin{array}{l}\text { 1,2-bis(dimethylsilyl)benzene } \\
\text { /1,2-diiodobenzene }\end{array}$ & Yield $(\%)^{b}$ \\
\hline 1 & $\mathrm{Pd}\left(\mathrm{PPh}_{3}\right)_{4}$ & rt & THF & $(i-\mathrm{Pr})_{2} \mathrm{EtN}$ & 1.2 & 0 \\
\hline 2 & $\mathrm{Pd}\left(\mathrm{P}(t-\mathrm{Bu})_{3}\right)_{2}$ & rt & THF & $(i-\mathrm{Pr})_{2} \mathrm{EtN}$ & 1.2 & 6 \\
\hline 3 & $\mathrm{Pd}\left(\mathrm{P}(t-\mathrm{Bu})_{2} \mathrm{Ph}\right)_{2}$ & rt & THF & $(i-\mathrm{Pr})_{2} \mathrm{EtN}$ & 1.2 & 22 \\
\hline 4 & $\mathrm{Pd}\left(\mathrm{P}(t-\mathrm{Bu})_{2}\left(4-\mathrm{Me}_{2} \mathrm{NC}_{6} \mathrm{H}_{4}\right)\right)_{2}$ & $\mathrm{rt}$ & THF & $(i-\mathrm{Pr})_{2} \mathrm{EtN}$ & 1.2 & 27 \\
\hline 5 & $\mathrm{Pd}\left(\mathrm{P}(t-\mathrm{Bu})_{2}\left(4-\mathrm{Me}_{2} \mathrm{NC}_{6} \mathrm{H}_{4}\right)\right)_{2}$ & 50 & THF & $(i-\mathrm{Pr})_{2} \mathrm{EtN}$ & 1.2 & 22 \\
\hline 6 & $\mathrm{Pd}\left(\mathrm{P}(t-\mathrm{Bu})_{2}\left(4-\mathrm{Me}_{2} \mathrm{NC}_{6} \mathrm{H}_{4}\right)\right)_{2}$ & 0 & THF & $(i-\mathrm{Pr})_{2} \mathrm{EtN}$ & 1.2 & 6 \\
\hline 7 & $\mathrm{Pd}\left(\mathrm{P}(t-\mathrm{Bu})_{2}\left(4-\mathrm{Me}_{2} \mathrm{NC}_{6} \mathrm{H}_{4}\right)\right)_{2}$ & rt & $\mathrm{CH}_{3} \mathrm{CN}$ & $(i-\mathrm{Pr})_{2} \mathrm{EtN}$ & 1.2 & 33 \\
\hline 8 & $\mathrm{Pd}\left(\mathrm{P}(t-\mathrm{Bu})_{2}\left(4-\mathrm{Me}_{2} \mathrm{NC}_{6} \mathrm{H}_{4}\right)\right)_{2}$ & $\mathrm{rt}$ & $\mathrm{CH}_{3} \mathrm{CH}_{2} \mathrm{CN}$ & $(i-\mathrm{Pr})_{2} \mathrm{EtN}$ & 1.2 & 42 \\
\hline 9 & $\mathrm{Pd}\left(\mathrm{P}(t-\mathrm{Bu})_{2}\left(4-\mathrm{Me}_{2} \mathrm{NC}_{6} \mathrm{H}_{4}\right)\right)_{2}$ & $\mathrm{rt}$ & toluene & $(i-\mathrm{Pr})_{2} \mathrm{EtN}$ & 1.2 & 19 \\
\hline 10 & $\mathrm{Pd}\left(\mathrm{P}(t-\mathrm{Bu})_{2}\left(4-\mathrm{Me}_{2} \mathrm{NC}_{6} \mathrm{H}_{4}\right)\right)_{2}$ & rt & $\mathrm{CH}_{2} \mathrm{Cl}_{2}$ & $(i-\mathrm{Pr})_{2} \mathrm{EtN}$ & 1.2 & 36 \\
\hline 11 & $\mathrm{Pd}\left(\mathrm{P}(t-\mathrm{Bu})_{2}\left(4-\mathrm{Me}_{2} \mathrm{NC}_{6} \mathrm{H}_{4}\right)\right)_{2}$ & rt & $\mathrm{CHCl}_{3}$ & $(i-\mathrm{Pr})_{2} \mathrm{EtN}$ & 1.2 & 15 \\
\hline 12 & $\mathrm{Pd}\left(\mathrm{P}(t-\mathrm{Bu})_{2}\left(4-\mathrm{Me}_{2} \mathrm{NC}_{6} \mathrm{H}_{4}\right)\right)_{2}$ & rt & $\mathrm{ClCH}_{2} \mathrm{CH}_{2} \mathrm{Cl}$ & $(i-\mathrm{Pr})_{2} \mathrm{EtN}$ & 1.2 & 38 \\
\hline 13 & $\mathrm{Pd}\left(\mathrm{P}(t-\mathrm{Bu})_{2}\left(4-\mathrm{Me}_{2} \mathrm{NC}_{6} \mathrm{H}_{4}\right)\right)_{2}$ & $\mathrm{rt}$ & $\mathrm{CH}_{3} \mathrm{CH}_{2} \mathrm{CN}$ & $\mathrm{Et}_{3} \mathrm{~N}$ & 1.2 & 40 \\
\hline 14 & $\mathrm{Pd}\left(\mathrm{P}(t-\mathrm{Bu})_{2}\left(4-\mathrm{Me}_{2} \mathrm{NC}_{6} \mathrm{H}_{4}\right)\right)_{2}$ & $\mathrm{rt}$ & $\mathrm{CH}_{3} \mathrm{CH}_{2} \mathrm{CN}$ & DABCO & 1.2 & 4 \\
\hline 15 & $\mathrm{Pd}\left(\mathrm{P}(t-\mathrm{Bu})_{2}\left(4-\mathrm{Me}_{2} \mathrm{NC}_{6} \mathrm{H}_{4}\right)\right)_{2}$ & rt & $\mathrm{CH}_{3} \mathrm{CH}_{2} \mathrm{CN}$ & $c-\mathrm{C}_{6} \mathrm{H}_{11} \mathrm{MeN}$ & 1.2 & 31 \\
\hline 16 & $\mathrm{Pd}\left(\mathrm{P}(t-\mathrm{Bu})_{2}\left(4-\mathrm{Me}_{2} \mathrm{NC}_{6} \mathrm{H}_{4}\right)\right)_{2}$ & rt & $\mathrm{CH}_{3} \mathrm{CH}_{2} \mathrm{CN}$ & & 1.2 & 34 \\
\hline 17 & $\mathrm{Pd}\left(\mathrm{P}(t-\mathrm{Bu})_{2}\left(4-\mathrm{Me}_{2} \mathrm{NC}_{6} \mathrm{H}_{4}\right)\right)_{2}$ & $\mathrm{rt}$ & $\mathrm{CH}_{3} \mathrm{CH}_{2} \mathrm{CN}$ & & 1.2 & 0 \\
\hline 18 & $\mathrm{Pd}\left(\mathrm{P}(t-\mathrm{Bu})_{2}\left(4-\mathrm{Me}_{2} \mathrm{NC}_{6} \mathrm{H}_{4}\right)\right)_{2}$ & rt & $\mathrm{CH}_{3} \mathrm{CH}_{2} \mathrm{CN}$ & DBU & 1.2 & 0 \\
\hline 19 & $\mathrm{Pd}\left(\mathrm{P}(t-\mathrm{Bu})_{2}\left(4-\mathrm{Me}_{2} \mathrm{NC}_{6} \mathrm{H}_{4}\right)\right)_{2}$ & $\mathrm{rt}$ & $\mathrm{CH}_{3} \mathrm{CH}_{2} \mathrm{CN}$ & $\mathrm{K}_{3} \mathrm{PO}_{4}$ & 1.2 & 21 \\
\hline 20 & $\mathrm{Pd}\left(\mathrm{P}(t-\mathrm{Bu})_{2}\left(4-\mathrm{Me}_{2} \mathrm{NC}_{6} \mathrm{H}_{4}\right)\right)_{2}$ & rt & $\mathrm{CH}_{3} \mathrm{CH}_{2} \mathrm{CN}$ & $\mathrm{Cs}_{2} \mathrm{CO}_{3}$ & 1.2 & 16 \\
\hline 21 & $\mathrm{Pd}\left(\mathrm{P}(t-\mathrm{Bu})_{2}\left(4-\mathrm{Me}_{2} \mathrm{NC}_{6} \mathrm{H}_{4}\right)\right)_{2}$ & rt & $\mathrm{CH}_{3} \mathrm{CH}_{2} \mathrm{CN}$ & KOAc & 1.2 & 10 \\
\hline 22 & $\mathrm{Pd}\left(\mathrm{P}(t-\mathrm{Bu})_{2}\left(4-\mathrm{Me}_{2} \mathrm{NC}_{6} \mathrm{H}_{4}\right)\right)_{2}$ & rt & $\mathrm{CH}_{3} \mathrm{CH}_{2} \mathrm{CN}$ & $\mathrm{KO}(t-\mathrm{Bu})$ & 1.2 & 0 \\
\hline $23^{c}$ & $\mathrm{Pd}\left(\mathrm{P}(t-\mathrm{Bu})_{2}\left(4-\mathrm{Me}_{2} \mathrm{NC}_{6} \mathrm{H}_{4}\right)\right)_{2}$ & rt & $\mathrm{CH}_{3} \mathrm{CH}_{2} \mathrm{CN}$ & $(i-\mathrm{Pr})_{2} \mathrm{EtN}$ & 1.5 & 42 \\
\hline $24^{c}$ & $\mathrm{Pd}\left(\mathrm{P}(t-\mathrm{Bu})_{2}\left(4-\mathrm{Me}_{2} \mathrm{NC}_{6} \mathrm{H}_{4}\right)\right)_{2}$ & rt & $\mathrm{ClCH}_{2} \mathrm{CH}_{2} \mathrm{Cl}$ & $(i-\mathrm{Pr})_{2} \mathrm{EtN}$ & 1.5 & 43 \\
\hline
\end{tabular}

a Reaction conditions: Pd catalyst $(0.025 \mathrm{mmol})$, 1,2-bis(dimethylsilyl)benzene $(0.60 \mathrm{mmol})$,

1,2-diiodobenzene $(0.50 \mathrm{mmol})$, base $(3.0 \mathrm{mmol})$, solvent $(1.0 \mathrm{~mL}), \mathrm{rt}, 1 \mathrm{~d}$.

${ }^{\mathrm{b}} \mathrm{GC}$ yield with dodecane as an internal standard.

${ }^{\mathrm{c}}$ The amount of 1,2-bis(dimethylsilyl)benzene was $0.75 \mathrm{mmol}$. 


\section{Table 2}

Chemical structures of silicon-containing six-membered-ring molecules 1-8 synthesized by the coupling of 1,2-bis(dimethylsilyl)arenes (blue) and 1,2-diiodoarenes (red).

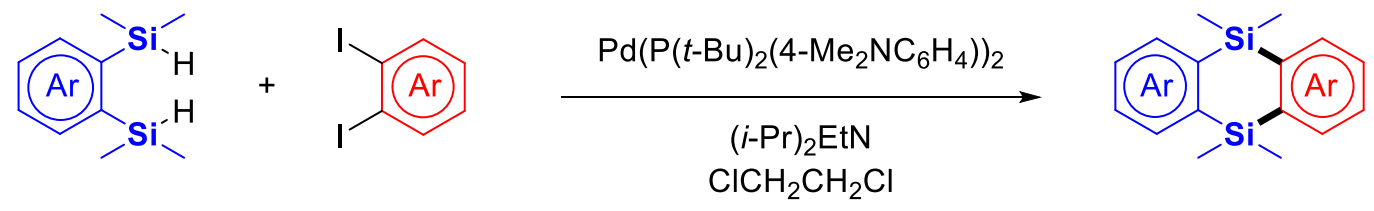<smiles>C[Si]1(C)c2ccccc2[Si](C)(C)c2ccccc21</smiles>

$1,43 \%$ b<smiles>COc1cc2c(cc1OC)[Si](C)(C)c1ccccc1[Si]2(C)C</smiles>

$4,37 \%$ b<smiles>C[Si]1(C)c2ccccc2[Si](C)(C)c2cc3ccccc3cc21</smiles>

$7,39 \%$<smiles>Cc1ccc2c(c1)[Si](C)(C)c1ccccc1[Si]2(C)C</smiles>

$2,27 \%$ b<smiles>C[Si]1(C)c2ccccc2[Si](C)(C)c2cc(F)ccc21</smiles>

$5,27 \%^{b}$<smiles>C[Si]1(C)c2ccccc2[Si](C)(C)c2cc3c(cc21)[Si](C)(C)c1ccccc1[Si]3(C)C</smiles>

8, $15 \%^{b}$<smiles>Cc1cc2c(cc1C)[Si](C)(C)c1ccccc1[Si]2(C)C</smiles>

$3,23 \%$ b<smiles>COC(=O)c1cc2c(cc1C(C)=O)[Si](C)(C)c1ccccc1[Si]2(C)C</smiles>

6, $25 \%^{b}$

9

${ }^{a}$ Reaction conditions: $\mathrm{Pd}\left(\mathrm{P}(t-\mathrm{Bu})_{2}\left(4-\mathrm{Me}_{2} \mathrm{NC}_{6} \mathrm{H}_{4}\right)\right)_{2}(0.025 \mathrm{mmol})$, 1,2-bis(dimethylsilyl)arene $(0.75 \mathrm{mmol})$, 1,2-diiodoarene (0.50 mmol), $(i \text {-Pr })_{2} \operatorname{EtN}(3.0 \mathrm{mmol}), 1,2$-dichloroethane $(1.0 \mathrm{~mL}), \mathrm{rt} ., 1 \mathrm{~d}$.

${ }^{\mathrm{b}} \mathrm{GC}$ yield with dodecane as an internal standard.

${ }^{\mathrm{c}}{ }^{1} \mathrm{H}$ NMR yield by the comparison with methyl proton integrals at $\delta 0.56$ vs 0.68 and 0.88 . 
Table 3

Optical properties of compounds 1-9 in hexane. ${ }^{\text {a }}$

\begin{tabular}{|c|c|c|c|c|c|c|c|}
\hline Compound & $\lambda_{\mathrm{abs}}(\mathrm{nm})^{\mathrm{b}}$ & $\varepsilon\left(\mathrm{dm}^{3} \mathrm{~mol}^{-1} \mathrm{~cm}^{-1}\right)$ & $\lambda_{\mathrm{ex}}(\mathrm{nm})$ & $\lambda_{\mathrm{em}}(\mathrm{nm})^{\mathrm{c}}$ & Stokes shift $\left(\mathrm{cm}^{-1}\right)$ & $\Phi_{\mathrm{F}}^{\mathrm{d}}$ & $\tau_{\mathrm{F}}(\mathrm{ns})^{\mathrm{e}}$ \\
\hline 1 & $\underline{266}, 271,277$ & $486,483,273$ & 266 & $-f^{f}$ & $-f^{f}$ & $-{ }^{f}$ & $-g$ \\
\hline 2 & 265,272 & 502,532 & 272 & 314 & 4920 & $<0.01$ & $-g$ \\
\hline 3 & $265, \underline{272}$ & 526,575 & 272 & 303 & 3760 & $<0.01$ & $-g$ \\
\hline 4 & $\underline{286}, 292$ & 3015,2863 & 286 & 317 & 3420 & 0.13 & 1.0 \\
\hline 5 & $\underline{270}, 277$ & 776,674 & 270 & 312 & 4990 & $<0.01$ & $-g$ \\
\hline 6 & $\underline{286}, 292$ & 1506,1480 & 286 & 341 & 5640 & 0.01 & 0.3 \\
\hline 7 & $267, \underline{275}, 284,297$ & $4327,4770,4272,2279$ & 275 & 344 & 7290 & 0.09 & 36 \\
\hline 8 & 289 & 336 & 289 & 354 & 6353 & $<0.01$ & $-\mathrm{g}$ \\
\hline 9 & $256, \underline{263}, 271$ & $489,690,598$ & 263 & 286 & 3060 & 0.07 & $-{ }^{h}$ \\
\hline
\end{tabular}

${ }^{a}$ All measurements were carried out at rt. Underlined values are wavelengths which have highest peak intensity.

${ }^{\mathrm{b}}$ Maximum absorption wavelength.

${ }^{\mathrm{c}}$ Maximum fluorescence wavelength excited at $\lambda_{\mathrm{ex}}$.

${ }^{\mathrm{d}}$ Absolute fluorescent quantum yield measured with an integrating sphere.

${ }^{\mathrm{e}}$ Fluorescence lifetime measured by photoexcitation at $280 \mathrm{~nm}$.

${ }^{\mathrm{f}}$ Emission wavelength, Stokes shift, and quantum yield could not be determined accurately due to the weak fluorescence.

${ }^{g}$ Fluorescence lifetime could not be determined accurately due to the weak fluorescence.

${ }^{\mathrm{h}}$ Fluorescence lifetime could not be determined accurately due to the small Stokes shift. 


\section{Table 4}

Optical properties of compounds 1-9 in the solid state. ${ }^{\mathrm{a}}$

\begin{tabular}{c|ccc}
\hline Compound & $\lambda_{\mathrm{ex}}(\mathrm{nm})$ & $\lambda_{\mathrm{em}}(\mathrm{nm})^{\mathrm{b}}$ & $\Phi_{\mathrm{F}}{ }^{\mathrm{c}}$ \\
\hline $\mathbf{1}$ & 295 & 351,359 & 0.06 \\
$\mathbf{3}$ & 280 & 305 & $<0.01$ \\
$\mathbf{4}$ & 276 & 305 & 0.12 \\
$\mathbf{5}$ & 286 & 321,348 & 0.09 \\
$\mathbf{6}$ & 299 & 304 & $<0.01$ \\
$\mathbf{7}$ & 323 & 326 & $<0.01$ \\
$\mathbf{8}$ & 290 & 359 & 0.27 \\
\hline $\mathbf{9}$ & 270 & 290 & 0.01 \\
\hline
\end{tabular}

${ }^{a}$ All measurements were carried out at rt.

${ }^{\mathrm{b}}$ Maximum fluorescence wavelength excited at $\lambda_{\mathrm{ex}}$.

${ }^{\mathrm{c}}$ Absolute fluorescent quantum yield measured with an integrating sphere. 


\section{Table 5}

Phosphorescence of 1-9.

\begin{tabular}{c|cccc}
\hline Compound & $\lambda_{\text {ex }}(\mathrm{nm})$ & $\lambda_{\text {em }}(\mathrm{nm})$ & $\Phi_{\mathrm{P}}{ }^{\mathrm{c}}$ & $\tau_{\mathrm{p}}(\mathrm{ms})^{\mathrm{d}}$ \\
\hline $\mathbf{1}$ & 266 & 405 & 0.05 & 55 \\
$\mathbf{2}$ & 272 & 406 & 0.03 & 53 \\
$\mathbf{4}$ & 272 & 406 & 0.02 & 101 \\
$\mathbf{5}$ & 286 & 419 & 0.03 & 56 \\
$\mathbf{6}$ & 270 & 406 & 0.03 & 57 \\
$\mathbf{7}$ & 286 & 455 & 0.06 & 44 \\
$\mathbf{8}$ & 284 & 408,421 & 0.01 & 47 \\
\hline $\mathbf{9}$ & 263 & $-{ }^{\mathrm{b}}$ & $-\mathrm{b}$ & $-\mathrm{b}$ \\
\hline
\end{tabular}

${ }^{a}$ Phosphorescence was measured at $77 \mathrm{~K}$ in degassed 2-methyltetrahydrofuran.

${ }^{\mathrm{b}}$ These values could not be determined accurately due to very weak phosphorescence.

${ }^{c}$ The phosphorescence quantum yields were determined relative to that of benzophenone $\left(\Phi_{\mathrm{p}}=0.88\right.$ in EtOH at $77 \mathrm{~K})$ as a reference. $[10,11]$

${ }^{\mathrm{d}}$ Phosphorescence lifetime measured by photoexcitation at $\lambda_{\mathrm{ex}}$. 
Graphical Abstract

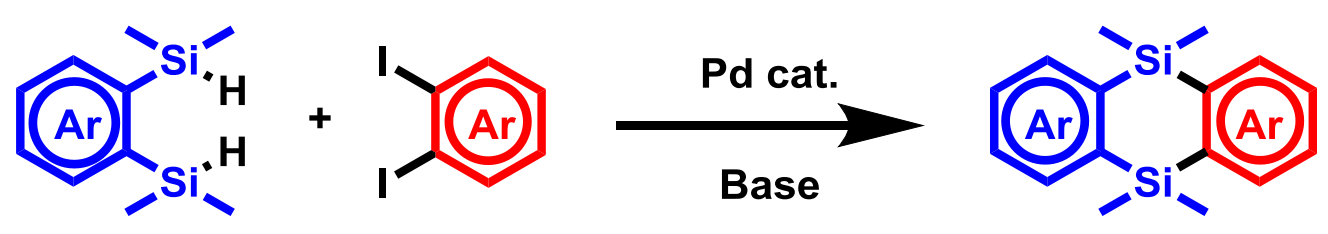

Up to $43 \%$

luminescence

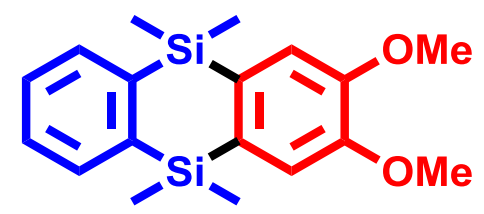

$\lambda_{\mathrm{em}}: 317 \mathrm{~nm}, \Phi_{\mathrm{F}}: 0.13$ phosphorescence

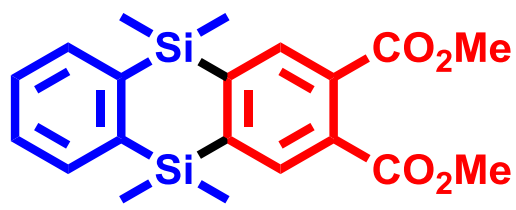

$\lambda_{\mathrm{em}}: 455 \mathrm{~nm}, \Phi_{\mathrm{p}}: 0.06$ 